\title{
PENGARUH VARIASI JARAK SUMBU KATUP LIMBAH DENGAN SUMBU TABUNG UDARA TERHADAP EFISIENSI POMPA HIDRAM
}

\author{
Asep Supriyanto', Dwi Irawan² \\ Jurusan Teknik Mesin, Fakultas Teknik, Universitas Muhammadiyah Metro ${ }^{1,2}$ \\ Jl. Ki Hajar Dewantara 15 A Metro, Lampung \\ email: asepsupriyanto1609@gmail.com ${ }^{1}$,dwi_irawan@yahoo.co.id ${ }^{2}$
}

\begin{abstract}
ABSTRAK
Usaha pemenuhan kebutuhan air dalam kehidupan sehari - hari dapat dilakukan dengan memanfaatkan kondisi alam ataupun dengan memanfaatkan peralatan mekanis hasil karya manusia. Pompa hidram merupakan salah satu jenis pompa yang digunakan untuk menaikkan air dari tempat rendah ke tempat yang lebih tinggi secara automatik dengan energi yang berasal dari air itu sendiri. Tujuan penelitian ini adalah untuk mengetahui pengaruh jarak sumbu katup limbah dengan sumbu tabung udara terhadap debit air keluaran (output) dan efisiensi yang dihasilkan. Metode yang digunakan yaitu dengan melakukan pengujian dengan variasi jarak sumbu katup limbah dengan sumbu tabung udara sepanjang $0,25 \mathrm{~m}, 0,35 \mathrm{~m}$, dan $0,45 \mathrm{~m}$ dan menggunakan katup limbah berdiam 4 inchi. Proses pengujian dilakukan pada masing-masing jarak dengan beban katup limbah 1,5 kg, tinggi terjunan air masuk $\left(H_{1}\right)$ 1,7 m, diam pipa air masuk (input) 6 inchi dengan debit input $\left(Q_{i n}\right) 0,084 \mathrm{~m}^{3} /$ detik dan tinggi angkat air $\left(\mathrm{H}_{2}\right) 5 \mathrm{~m}$ dengan panjang pipa penghantar (PP) $50 \mathrm{~m}$. Dari hasil penelitian yang telah dilakukan pada variasi jarak $0,25 \mathrm{~m}$ mendapatkan debit output $0,0041 \mathrm{~m}^{3} /$ detik dengan efisiensi $14 \%$, pada jarak $0,35 \mathrm{~m}$ mendapatkan debit output $0,0026 \mathrm{~m}^{3} /$ detik dengan efisiensi $9 \%$ dan pada pada jarak 0,45 m mendapatkan debit output $0,0023 \mathrm{~m}^{3} /$ detik dengan efisiensi $7 \%$.
\end{abstract}

Kata kunci: Pompa Hidram, Jarak Sumbu, Efisiensi, Beban Katup.

\section{PENDAHULUAN}

Air adalah sumber kehidupan yang dibutuhkan oleh makhluk hidup di bumi, terutama manusia. Manusia membutuhkan air untuk memenuhi kebutuhan sehari-hari.

Masyarakat yang berdomisili pada daerah di bawah sumber air tidak perlu bersusah payah menyediakan air untuk kehidupan mereka sehari - hari. Karena sesuai dengan hukum fisika, air akan mengalir dari tempat yang tinggi ke tempat yang rendah. Jadi bagi mereka yang tinggal di daerah seperti itu, tinggal membuat jalur - jalur perpipaan untuk mengalirkan air ke rumah - rumah mereka. Sedangkan bagi masyarakat yang berada jauh dari sumber air atau berada pada daerah yang lebih tinggi dari pada sumber air, dapat menggunakan peralatan mekanis untuk membantu dalam penyediaan air.

Pompa adalah peralatan mekanis untuk mengubah energi mekanik dari mesin penggerak pompa menjadi energi tekan fluida yang dapat membantu memindahkan fluida ke tempat yang lebih tinggi elevasinya.

Pompa hidram adalah suatu alat untuk menaikan air dari tempat rendah ke tempat yang lebih tinggi, pompa ini tidak membutuhkan sumber energi listrik maupun bahan bakar, dan dapat bekerja terus menerus, tidak membutuhkan pelumasan, biaya pembuatan dan perawatan murah, bentuknya sederhana, dan dapat menaikkan air ke tempat rendah ke tempat yang lebih tinggi. Sehingga pompa ini sangat tepat untuk daerah-daerah yang jauh dari sumber listrik, karena pompa ini pemeliharaannya sangat sederhana.

Mekanisme pompa hidram (Hydraulic Ram Pump) yaitu air masuk dari terjunan melalui pipa penghantar masuk kekatup limbah atau katup pembuangan 
dan didorong kekatup penghisap yang akan membuka akibat dorongan air dan akan masuk ke tabung kompresi. Pada saat tabung berisi air dan udara secara maksimal maka sebagian air akan keluar melalui pipa penghantar dan menaikkan air ke daerah yang lebih tinggi. Air kembali masuk dan mengakibatkan ram (palu air) water hammer mendorong air masuk ketabung kompresesi. 2/3 air akan terbuang melalui katub limbah dan 1/3 akan naik melalui pipa penghantar. Energi yang berulang ulang mendorong air ketempat yang lebih tinggi.

Penelitian Susana dan Sutanto yang tentang peningkatan kinerja pompa hidram berdasarkan posisi tabung kompresor dengan saluran keluar di bawah tabung kompresor [1], dengan melakukan pengujian terhadap perubahan posisi tabung kompresor yaitu dengan susunan input-tabung kompresor- katup limbah (IKL) dan input-katup limbah-tabung kompresor (ILK) dengan saluran keluar berada di bawah tabung kompresor dan memvariasikan tinggi jatuhan 1,6" 2,1" 2,6" 3,1" 3,6" 4,1" dan 4,6 m dengan diam input 1,5 inchi. Debit output terbesar terjadi pada tinggi terjunan $4,1 \mathrm{~m}$ dan meningkat dari 0,112 l/detik pada susunan IKL menjadi 0,121 1/detik yang tersusun ILK. Head maksimum terbesar terjadi pada tinggi terjunan 4,1 $\mathrm{m}$ dan meningkat dari 12 $\mathrm{m}$ pada susunan IKL menjadi $16 \mathrm{~m}$ pada susunan ILK. Efisiensi terbesar terjadi pada tinggi terjunan $3,1 \mathrm{~m}$ dan meningkat dari 2,357\% pada susunan IKL menjadi 2,618\% pada susunan ILK.

Pada tahun 2013, Setyawan melakukan penelitian dengan judul pengaruh berat katup limbah dan ketinggian discharge terhadap kinerja pompa hidram [2]. Dari penelitian yang telah dilakukan menunjukan bahwa kapasitas pompa dipengaruhi oleh berat katup limbah, semakin berat katup limbah semakin sedikit ketukan yang dihasilkan semakin tinggi discharge semakin berkurang kapasitas discharge. Variabel berat katup limbah 200, 250, 300, 350, 400,
450 gram pada pompa dengan ketinggian sumber air $200 \mathrm{~cm}$, panjang pipa inlet 400 $\mathrm{cm}$, diam pipa inlet $11 / 4$ inchi, volume tabung $0,0031 \mathrm{~m}^{3}$, menunjukan kapasitas terbaik pada berat katup limbah 200 gram dengan ketinggian discharge $300 \mathrm{~cm}$, dengan hasil kapasitas 7,75 1/min. Menunjukan bahwa efisiensi pompa dipengaruhi oleh kapasitas discharge dan kapasitas limbah. Sedangkan kapasitas dipengaruhi oleh berat katup. Semakin berat katup limbah semakin sedikit ketukan yang dihasilkan. Semakin tinggi discharge semakin berkurang kapassitas discharge. Efisiensi volumetris terbaik pada berat katup limbah 200 gram dengan nilai 52,961 $\%$ pada discharge $300 \mathrm{~cm}$, efisiensi pompa terbaik pada ketinggian discharge dan berat katup limbah 200 gram dengan nilai 60,623 $\%$.

Berdasarkan hasil uraian di atas, maka masih perlu dikembangkan penelitian lanjutan tentang efisiensi kinerja pompa hidram, hal ini menarik penulis untuk melakukan penelitian tentang "Uji Eksperimental Pengaruh Variasi Jarak Sumbu Katup Limbah Dengan Sumbu Katup Limbah".

Tujuan dari penulisan penelitian ini untuk Mengetahui pengaruh jarak sumbu tabung udara dengan sumbu katup limbah terhadap debit air yang dihasilkan (debit output) dan Mengetahui pengaruh jarak sumbu tabung udara dengan sumbu katup limbah terhadap efisiensi pompa hidram.

Manfaat yang dicapai dalam penelitian ini adalah membantu masyarakat di Desa Rantau Fajar Kabupaten Lampung Timur dalam penyediaan air irigasi persawahan menggunakan peralatan yang lebih ekonomis, memberikan pengetahuan kepada mayarakat umum mengenai teknologi tepat guna, mengurangi penggunaan bahan bakar diesel maupun listrik dalam penyediaan air, dan sebagai referensi bacaan dalam penelitian pompa hidram selanjutnya. 


\section{TINJAUAN PUSTAKA}

\section{Pompa Hidram}

Pompa hidram merupakan suatu alat yang digunakan untuk menaikkan air dari tempat rendah ke tempat yang lebih tinggi secara automatik dengan energi yang berasal dari air itu sendiri. Pompa hidram bekerja tanpa menggunakan bahan bakar atau tambahan energi dari luar [3].

Pompa hidram pertama kali dibuat oleh John Whitehurst seorang peneliti asal Inggris pada tahun 1772. Pompa hidram buatan Whitehurst masih berupa hidram manual, di mana katup limbah masih digerakkan secara manual. Pompa ini pertama kali digunakan untuk menaikkan air sampai ketinggian 4,9 m (16 kaki). Pada tahun 1783, Whitehusrt memasang pompa sejenis ini di Irlandia untuk keperluan air bersih sehari - hari.

Pompa hidram otomatis pertama kali dibuat oleh seorang ilmuwan Prancis bernama Joseph Michel Montgolfier pada tahun 1796. Desain pompa buatan Montgolfier sudah menggunakan 2 buah katup (waste valve dan delivery valve) yang bergerak secara bergantian. Pompa ini kemudian digunakan untuk menaikkan air untuk sebuah pabrik kertas di daerah Voiron. Satu tahun kemudian, Matius Boulton, memperoleh hak paten atas pompa tersebut di Inggris.

Pada tahun 1820, melalui Easton's Firma yang mengkhususkan usahanya di bidang air dan sistem drainase, Josiah Easton mengembangkan hidram hingga menjadi usaha ram terbaik dalam penyediaan air bersih untuk keperluan rumah tangga, peternakan dan masyarakat desa. Pada tahun 1929, usaha Eastons ini dibeli oleh Green and Carter, yang kemudian meneruskan manufaktur ram tersebut.

Di Benua Amerika, hak paten hidram pertama kali di pegang oleh $\mathrm{J}$. Cernau dan SS Hallet, di New York. Pompa tersebut sebagian besar digunakan di derah pertanian dan peternakan. Memasuki periode berikutnya, kepopuleran hidram mulai berkurang, seiring berkembangnya pompa elektrik.

Di kawasan Asia, pompa hidram mulai dioperasikan di Taj Mahal, Agra, India pada tahun 1900. Pompa hidram yang di pasang di daerah tersebut adalah Black's Hydram yang dibuat oleh John Black Ltd., sebuah perusahaan asal Inggris. Black's Hydram digunakan untuk memompa air dengan debit 31,5 liter per detik. Selain di Agra, Black's Hydram juga dipasang di daerah Risalpur, Pakistan, pada tahun 1925. Ditempat itu, Black's Hydram berhasil memompa air hingga ketinggian 18,3 m dengan debit mencapai 56,5 Liter/detik.

Pada akhir abad 20, penggunaan pompa hidram kembali digalakkan lagi, karena kebutuhan pembangunan teknologi di negara - negara berkembang, dan juga karena isu konservasi energi dalam mengembangkan perlindungan ozon. Contoh pengembang pompa hidram yang baik adalah AID Foundation di Filipina, Mereka mengembangkan pompa hidram untuk digunakan di desa - desa terpencil. Oleh sebab itu mereka meraih Penghargaan Ashden.

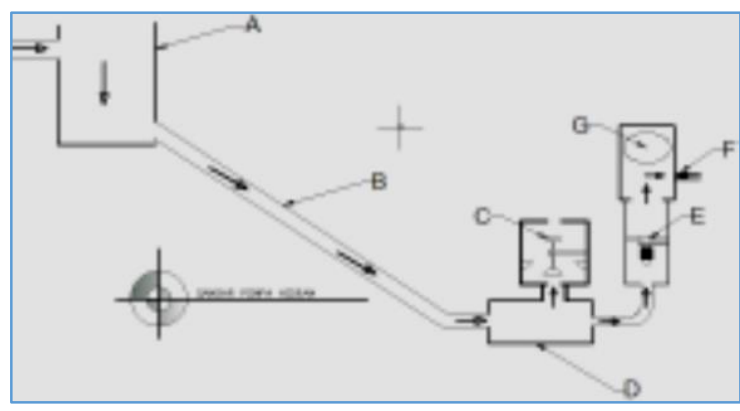

Gambar 1. Bagian-Bagian Pompa Hidram [4]

Keterangan :
A. Water Source Tank
B. Pipa Masuk (Drive Pipe)
C. Katup limbah (Waste Valve)
D. Badan Hidram
E. Katub Penghantar (delivery valve)
F. Pipa Penghantar (Delivery Pipe)
G. Tabung udara (Air Chamber)

\section{Efisiensi Pompa Hidram}

Efisiensi adalah perbandingan
masukan (input) dengan pngeluaran


(output) ataupun ketepatan cara usaha kerja terhadap hasil didalam proses suatu unit kerja, efisiensi selalu menjadi pertimbangan penting pada proses unit kerja. Karena salah satu faktor performansinya dapat dilihat dari besar kecilnya efisiensi yang dihasilkan. Menurut perhitungan D'aubuisson efisiensi pompa hidram dapat dihitung dengan persamaan [5]:

$$
\eta=\frac{Q_{o u t} \times H_{2}}{\left(Q_{L}+Q_{o u t}\right) \times H_{1}}
$$

Keterangan:

$\eta \quad=$ efisiensi pompa hidram $D$ 'aubuisson $Q_{\text {out }}=$ debit hasil air keluaran/debit output $\left(\mathrm{m}^{3} / \mathrm{s}\right)$

$Q_{L}=$ kapasitas debit limbah $\left(\mathrm{m}^{3} / \mathrm{s}\right)^{*}$

$H_{1}=$ tinggi jatuh (m)

$\mathrm{H}_{2}$ = tinggi angkat (m)

*Kapasitas limbah $\left(Q_{L}\right)=$ Debit air masuk pada pompa hidram ( Qin ) - Debit hasil Keluaran ( Qout)

\section{METODE PENELITIAN}

Untuk meningkatkan kinerja pompa hidram dalam penelitian ini dilakukan kajian terhadap pengaruh variasi jarak sumbu udara dengan sumbu katup limbah yang dikaji berdasarkan debit air keluar (output) dan efisiensi.

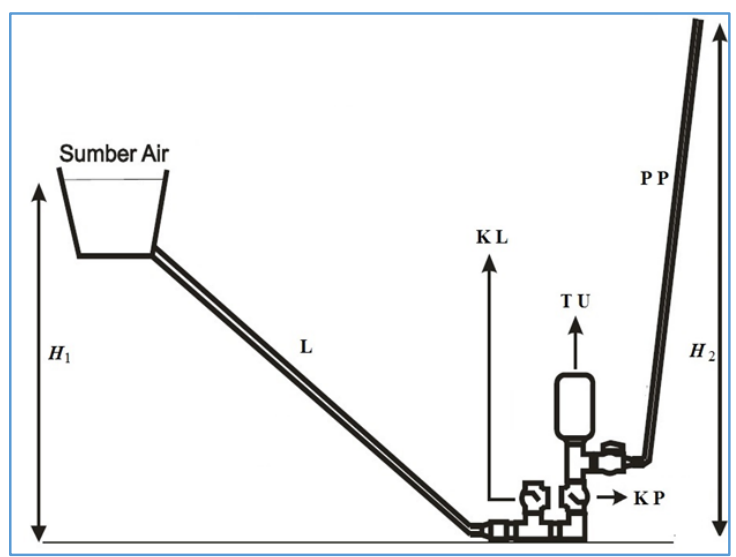

Gambar 2. Rangkaian Pompa hidram

Lokasi pemasangan pompa hidram ditentukan pada ketinggian air masuk dan panjang pipa masuk dititik terbawah maksimal dari sumber air yaitu pada ketinggian dari sumber air masuk ( H1 ) 1,7 $\mathrm{m}$ dan panjang pipa input ( L ) $16 \mathrm{~m}$ dengan menggunakan pipa diam 6 inchi maka didapat debit air dari pipa input ( Qin ) $0,084 \mathrm{~m}^{3} /$ detik. Lokasi tujuan pipa hasil air keluaran ditentukan pada ktinggian ( H2 ) 5 $\mathrm{m}$ dengan panjang pipa $50 \mathrm{~m}$ karena target persawahan yang akan dialiri air berada pada ukuran tersebut.

Pengujian diawali dengan mempersiapkan alat dan bahan yang dibutuhkan, kemudian dirakit sesuai dengan instalasi yang dibutuhkan untuk pengujian, simulasi kesesuaian alat ukur, dan simulasi metode pengambilan data dan selanjutnya pengujian pada 3 variasi jarak sumbu tabung udara ke sumbu katub limbah yaitu pada jarak $0,25 \mathrm{~m}, 0,35 \mathrm{~m}$, dan 0,45 m dengan menggunakan katup limbah diam 4 inchi beban katup 1,5 $\mathrm{kg}$ pada ketinggian $\mathrm{H}_{2} 5 \mathrm{~m}$ dan selanjutnya pengujian yang sama dilakukan pada ketinggian $\mathrm{H}_{2} 15 \mathrm{~m}$. Proses pengambilan debit $\mathrm{H}_{2}$ dengan cara menggunakan gelas ukur dan dilakukan sebanyak lima kali proses pengambilan data pada setiap ketinggian $\mathrm{H}_{2}$.

1. Variasi jarak 1 (Pertama)

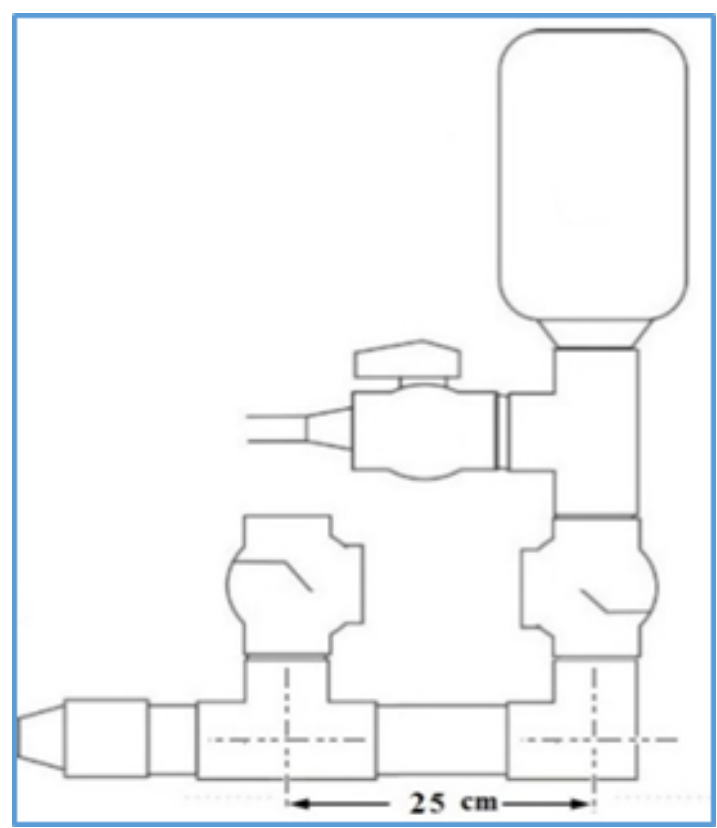

Gambar 3. Jarak 0,25 m 
2. Variasi jarak 2 (Kedua)

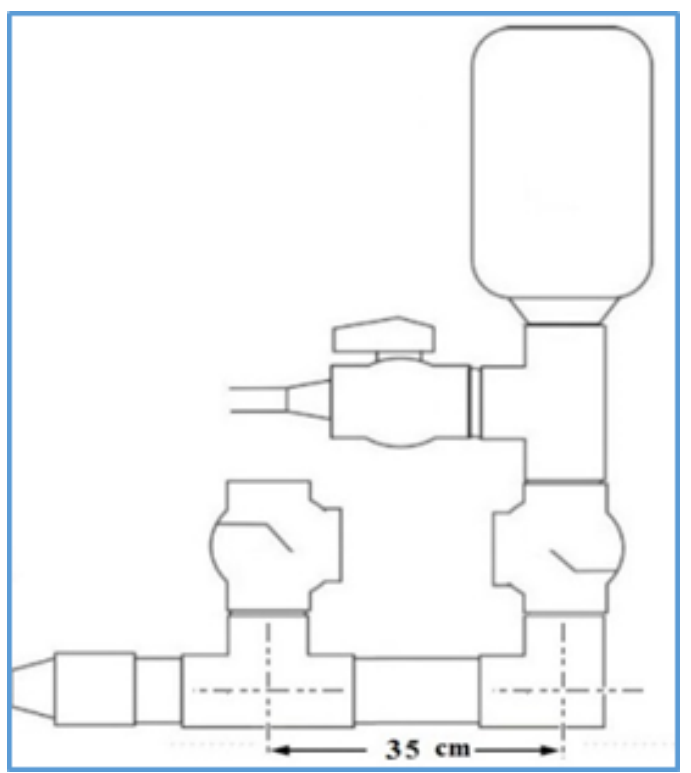

Gambar 4. Jarak 0,35 m

3. Variasi jarak 3 (Ketiga)

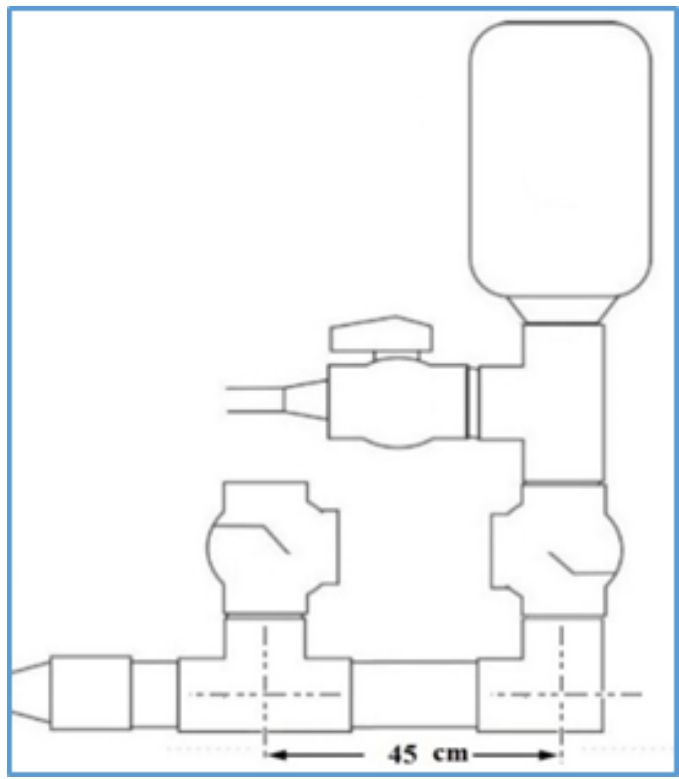

Gambar 5. Jarak 0,45 m
HASIL DAN PEMBAHASAN

Hasil Pengujian Pada Jarak 0,25 m

Tabel 1. Hasil pengujian pada jarak $0,25 \mathrm{~m}$

\begin{tabular}{|c|c|c|c|c|}
\hline $\begin{array}{l}\text { Ketinggi } \\
\text { an } \mathrm{H}_{2} \\
\text { (m) }\end{array}$ & $\begin{array}{c}\text { Debit } \\
\text { input } \\
\left(\mathrm{m}^{3} / \text { detik }\right)\end{array}$ & $\begin{array}{l}\text { Volume } \\
\text { output } \\
\left(\mathrm{m}^{3}\right)\end{array}$ & $\begin{array}{l}\text { Waktu } \\
\text { (detik) }\end{array}$ & $\begin{array}{c}\text { Debit } \\
\text { output } \text { air } \\
\text { ( } \mathrm{m}^{3} / \text { detik) }\end{array}$ \\
\hline \multirow{5}{*}{5} & \multirow{5}{*}{0,0084} & \multirow{5}{*}{0,001} & 2,38 & 0,00042 \\
\hline & & & 2,30 & 0,00043 \\
\hline & & & 2,44 & 0,0004 \\
\hline & & & 2,48 & 0,0004 \\
\hline & & & 2,48 & 0,0004 \\
\hline \multicolumn{3}{|c|}{ Rata - rata } & 2,41 & 0,00041 \\
\hline \multirow{5}{*}{15} & \multirow{5}{*}{0,0084} & \multirow{5}{*}{0,001} & 3,77 & 0,000265 \\
\hline & & & 3,83 & 0,000261 \\
\hline & & & 3,78 & 0,000264 \\
\hline & & & 3,88 & 0,000257 \\
\hline & & & 3,76 & 0,000265 \\
\hline \multicolumn{3}{|c|}{ Rata - rata } & 3,81 & 0,00026 \\
\hline
\end{tabular}

Dari hasil pengujian (Tabel 1) jarak sumbu tabung udara dengan sumbu katup limbah 0,25 m didapakan hasil debit output pada $\mathrm{H}_{2} 5 \mathrm{~m}$ yaitu $0,0041 \mathrm{~m}^{3} /$ detik dan $\mathrm{H}_{2}$ $15 \mathrm{~m}$ yaitu $0,0026 \mathrm{~m}^{3} /$ detik.

\section{Hasil Pengujian Pada Jarak 0,35 m}

Tabel 2. Hasil pengujian pada jarak $0,35 \mathrm{~m}$

\begin{tabular}{|c|c|c|c|c|}
\hline $\begin{array}{c}\text { Keting } \\
\text { gian } \\
\mathrm{H}_{2} \\
\text { (m) }\end{array}$ & $\begin{array}{c}\text { Debit } \\
\text { input } \\
\left(\mathrm{m}^{3} / \text { detik }\right)\end{array}$ & $\begin{array}{c}\text { Volume } \\
\text { output } \\
\left(\mathrm{m}^{3}\right)\end{array}$ & $\begin{array}{l}\text { Waktu } \\
\text { (detik) }\end{array}$ & $\begin{array}{c}\text { Debit output air } \\
\left(\mathrm{m}^{3} / \mathrm{detik}\right)\end{array}$ \\
\hline \multirow{5}{*}{5} & \multirow{5}{*}{0,0084} & \multirow{5}{*}{0,001} & 3,87 & 0,000258 \\
\hline & & & 3,73 & 0,000268 \\
\hline & & & 3,78 & 0,000264 \\
\hline & & & 3,73 & 0,000268 \\
\hline & & & 3,74 & 0,000267 \\
\hline \multicolumn{3}{|c|}{ Rata - rata } & 3,77 & 0,00026 \\
\hline \multirow{5}{*}{15} & \multirow{5}{*}{0,0084} & \multirow{5}{*}{0,001} & 5,84 & 0,000171 \\
\hline & & & 5,95 & 0,000168 \\
\hline & & & 5,78 & 0,000173 \\
\hline & & & 5,81 & 0,000172 \\
\hline & & & 5,87 & 0,000170 \\
\hline \multicolumn{3}{|c|}{ Rata - rata } & 5,85 & 0,00017 \\
\hline
\end{tabular}

Dari hasil pengujian (Tabel 2) jarak $0,35 \mathrm{~m}$ didapakan hasil debit output pada $H_{2} 5 \mathrm{~m}$ yaitu $0,0026 \mathrm{~m}^{3} /$ detik dan $H_{2} 15 \mathrm{~m}$ yaitu $0,0017 \mathrm{~m}^{3} /$ detik. 
Hasil Pengujian Pada Jarak 0,45 m

Tabel 3. Hasil pengujian pada jarak 0,45 m

\begin{tabular}{|c|c|c|c|c|}
\hline $\begin{array}{c}\text { Ketinggian } \\
\mathrm{H}_{2} \\
(\mathrm{~m})\end{array}$ & $\begin{array}{c}\text { Debit } \\
\text { input } \\
\left(\mathrm{m}^{3} / \text { detik }\right)\end{array}$ & $\begin{array}{c}\text { Volume } \\
\text { output } \\
\left(\mathrm{m}^{3}\right)\end{array}$ & $\begin{array}{l}\text { Waktu } \\
\text { (detik) }\end{array}$ & $\begin{array}{c}\text { Debit } \\
\text { output } \text { air } \\
\left(\mathrm{m}^{3} / \text { detik }\right)\end{array}$ \\
\hline \multirow{5}{*}{5} & \multirow{5}{*}{0,0084} & \multirow{5}{*}{0,001} & 4,38 & 0,000228 \\
\hline & & & 4,43 & 0,000225 \\
\hline & & & 4,42 & 0,000226 \\
\hline & & & 4,44 & 0,000225 \\
\hline & & & 4,43 & 0,000225 \\
\hline \multicolumn{3}{|c|}{ Rata - rata } & 4,42 & $\mathbf{0 , 0 0 0 2 3}$ \\
\hline \multirow{5}{*}{15} & \multirow{5}{*}{0,0084} & \multirow{5}{*}{0,001} & 6,62 & 0,000151 \\
\hline & & & 6,69 & 0,000149 \\
\hline & & & 6,61 & 0,000151 \\
\hline & & & 6,61 & 0,000151 \\
\hline & & & 6,68 & 0,000149 \\
\hline \multicolumn{3}{|c|}{ Rata - rata } & 6,64 & 0,00015 \\
\hline
\end{tabular}

Dari hasil pengujian ( Tabel 3) jarak sumbu tabung udara dengan sumbu katup limbah $0,45 \mathrm{~m}$ didapakan hasil debit output pada $H_{2} 5 \mathrm{~m}$ yaitu $0,0023 \mathrm{~m}^{3} /$ detik dan $H_{2}$ $15 \mathrm{~m}$ yaitu $0,0015 \mathrm{~m}^{3} /$ detik.

\section{Efisiensi Pompa Hidram}

Dari hasil pengujian dan hasil perhitungan (Efisiensi pompa hidram D'aubuisson) jarak sumbu tabung udara dengan sumbu katup limbah $\mathbf{0 , 2 5} \mathbf{m}$ pada $\mathrm{H}_{2} 5 \mathrm{~m}$ yaitu $14 \%$ dan $H_{2} 15$ m yaitu $27 \%$, pada jarak $\mathbf{0 , 3 5} \mathbf{m ~} \mathrm{H}_{2} 5 \mathrm{~m}$ yaitu $9 \%$ dan $\mathrm{H}_{2}$ $15 \mathrm{~m}$ yaitu $17 \%$, sedangkan pada jarak $\mathbf{0 , 4 5}$ m $\mathrm{H}_{2} 5$ m yaitu $8 \%$ dan $\mathrm{H}_{2} 15$ m yaitu $16 \%$.

$$
\text { Hasil pengujian dengan }
$$
menggunakan beban katup 1,5 kg kemudian air mampu naik hingga ketinggian $\mathrm{H}_{2} 5 \mathrm{~m}$ dengan panjang pipa output $50 \mathrm{~m}$ dihasilkan debit output $0,00041 \mathrm{~m}^{3} /$ detik pada jarak sumbu tabung udara dengan sumbu katup limbah $0,25 \mathrm{~m}$ dan pada $H_{2} 15 \mathrm{~m}$ yaitu $0,00026 \mathrm{~m}^{3} /$ detik.

Langkah langkah tersebut dilakukan pada jarak sumbu tabung udara dengan sumbu katup limbah $0,35 \mathrm{~m}$ dan 0,45 m dengan ketinggian $H_{2}$ yang sama pada masing - masing jarak sumbu tabung udara dengan sumbu katup limbah didapatkan hasil yang bervariasi. Hasil debit output pada jarak $0,35 \mathrm{~m}$ pada $H_{2} 5 \mathrm{~m}$ yaitu $0,00026 \mathrm{~m}^{3} /$ detik dan $H_{2} 15 \mathrm{~m}$ yaitu $0,00017 \mathrm{~m}^{3} /$ detik, sedangkan hasil debit output pada jarak $0,45 \mathrm{~m} \mathrm{H}_{2} 5 \mathrm{~m}$ yaitu $0,00023 \mathrm{~m}^{3} /$ detik dan $H_{2} 15 \mathrm{~m}$ yaitu $0,00015 \mathrm{~m}^{3} /$ detik.

Pada masing masing jarak sumbu tabung udara ke sumbu katup limbah mendapatkan nilai efisiensi yang berbeda beda, efisiensi tertinggi didapatkan pada jarak 0,25 m pada ketinggian $\mathrm{H}_{2} 15 \mathrm{~m}$ yaitu $27 \%$ dan $\mathrm{H}_{2} 5$ m yaitu sebesar $14 \%$, pada jarak 0,35 m ketinggian $H_{2} 15 \mathrm{~m}$ yaitu $17 \%$ dan $\mathrm{H}_{2} 5 \mathrm{~m}$ yaitu sebesar $9 \%$, sedangkan pada jarak $0,45 \mathrm{~m} \mathrm{H}_{2} 15 \mathrm{~m}$ hanya $16 \%$ dan $\mathrm{H}_{2} 5 \mathrm{~m}$ yaitu hanya $8 \%$.

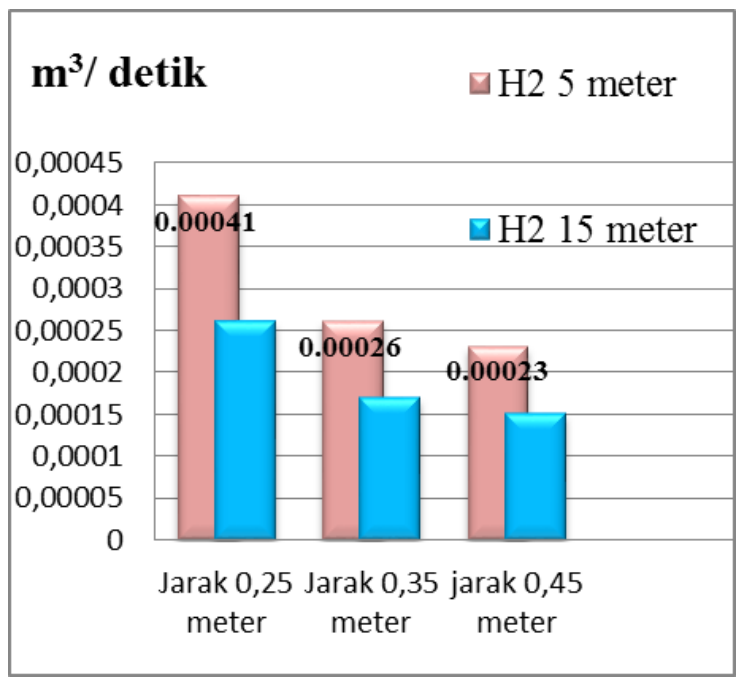

Gambar 6. Grafik Perbandingan Hasil

Debit Output Pada Variasi Jarak Sumbu

Tabung Udara Dengan Sumbu Katup Limbah

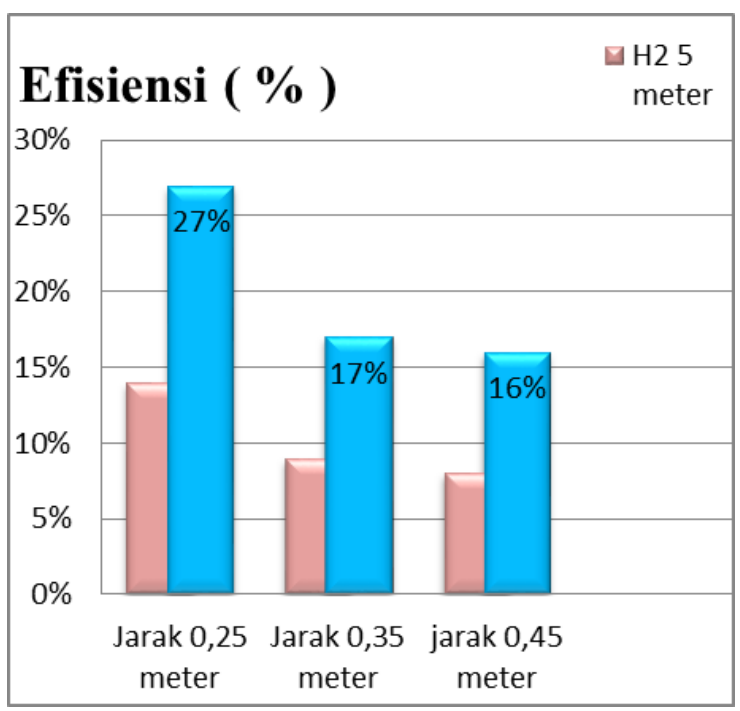

Gambar 7. Grafik Perbandingan Efisiensi

Nilai - nilai hasil debit output dan efisiensi yang berbeda tersebut dipengaruhi 
oleh jarak sumbu tabung udara dengan sumbu katup limbah karena jika jarak sumbu tabung udara dengan sumbu katup limbah semakin dekat maka debit output akan semakin banyak. Sedangkan pada jarak $0,25 \mathrm{~m}, 0,35 \mathrm{~m}$, dan 0,45 m debit air keluar dari katup limbah terbanyak dihasilkan pada jarak $0,45 \mathrm{~m}$ sehingga debit output pada jarak $0,45 \mathrm{~m}$ menjadi lebih sedikit dari jarak $0,35 \mathrm{~m}$ dan $0,25 \mathrm{~m}$.

Debit output juga dipengaruhi oleh penentuan beban katup, karena berat beban katup yang sama tetapi pada jarak sumbu tabung udara dengan sumbu katup limbah yang berbeda tidak selalu mendapatkan hasil debit air keluaran yang optimal.

\section{KESIMPULAN}

Dari hasil penelitian yang telah dilakukan pada variasi jarak sumbu tabung udara dengan sumbu katup limbah dapat di simpulkan sebagai berikut:

1. Debit output pada jarak sumbu tabung udara dengan sumbu katup limbah 0,25 m pada ketinggian $H_{2} 5$ m yaitu 0,0041

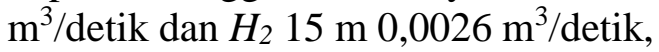
pada jarak $0,35 \mathrm{~m}$ ketinggian $\mathrm{H}_{2} 5 \mathrm{~m}$ yaitu $0,00026 \mathrm{~m}^{3} /$ detik dan $H_{2} 15 \mathrm{~m}$ $0,0017 \mathrm{~m}^{3} /$ detik sedangkan jarak 0,45 m ketinggian $\mathrm{H}_{2} 5 \mathrm{~m}$ yaitu 0,00023

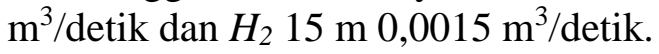

2. Efisiensi pada jarak sumbu tabung udara dengan sumbu katup limbah 0,25 m pada $H_{2} 5$ m yaitu $14 \%$ dan $H_{2} 15 \mathrm{~m}$ $27 \%$, pada jarak $0,35 \mathrm{~m}$ pada $H_{2} 5 \mathrm{~m}$ yaitu $9 \%$ dan $\mathrm{H}_{2} 15 \mathrm{~m} 17 \%$, sedangkan pada jarak $0,45 \mathrm{~m} \mathrm{H}_{2} 5 \mathrm{~m}$ yaitu $8 \%$ dan $\mathrm{H}_{2} 15 \mathrm{~m} 16 \%$.

\section{SARAN}

1. Untuk penggunaan beban katup limbah jangan terpaku pada satu variasi saja karena pada perbedaan jarak sumbu tabung udara ke sumbu katup limbah akan berbeda pula beban katup yang dapat mempengaruhi besar debit dan efisiensi pompa hidram.

2. Untuk mendapatkan hasil yang lebih akurat dalam penelitian pompa hidram di harapkan penggunaan alat ukur yang lebih akurat.

3. Untuk penelitian lebih lanjut perlu dilakukan penelitian untuk menentukan dimensi reduser katup limbah yang mampu menghasilkan Head tekanan dan efisiensi yang optimal pada pompa hidram.

4. Perlu adanya kesinambungan penelitian pompa hidram ini, agar teknologi hidram tidak berhenti, dan untuk membantu menyebarluaskan teknologi hidram ke daerah - daerah yang memungkinkan menjadi tempat instalasi hidram.

\section{DAFTAR PUSTAKA}

[1]. Susana, I. G. B., Sutanto, R., 2016, Peningkatan Kinerja Pompa Hidram Berdasarkan Posisi Tabung Kompresor Dengan Saluran Keluar Dibawah Tabung Kompresor, Teknik Mesin F.T Universitas Mataram, J1 Majapahit No. 62 Mataram, Nusa Tenggara Barat, 83125.

[2]. Setyawan, A. E., Siregar, I. H., 2015, Pengaruh Berat Katup Limbah Dan Ketinggian Discharge Terhadap Kinerja Pompa Hidram, S1 Pendidikan Teknik Mesin, Fakultas Teknik, Universitas Negeri Surabaya.

[3]. Hanafie, J., Longh, H. D., 1979, Teknologi Pompa Hidraulik Ram, Buku Petunjuk Untuk Pembuatan Dan Pemasangan.

[4]. Taufiq, Mohammad, D. A., Dkk., 2016, Pengaruh variasi jarak kerja katup penghantar (delivery valve) terhadap kinerja pompa hidram, Widya Teknika Vol. 24 No. 2.

[5]. Dinar M. F., Dkk. 2013. Uji Efisiensi $\begin{array}{lcc}\text { Pompa } & \text { Hidram Dengan } \\ \text { Variasi } & \text { Volume Tabung }\end{array}$ 
Udara, Prosiding Seminar Kontribusi Fisika, Bandung, Indonesia.

[6]. Ahmad Nur Arianta., 2010, Pengaruh

Variasi Ukuran Tabung

Udara Terhadap Unjuk Kerja

Sebuah Pompa Hidram,

Program Studi Teknik Mesin,

Jurusan Teknik Mesin,

Fakultas Teknik, Universitas

Gadjah Mada Yogyakarta.

[7]. Budiyanto, 2009, Pengaruh Tinggi

Dan Diam Inlet Terhadap Kapasitas Pompa Hidram Dengan Model Simulasi Program Delphi, Jurusan Teknik Mesin, Fakultas Teknologi Industri, Institut Teknologi Nasional Malang.

[8]. Browne, D. 2009, Design, Sizing, Construction And Maintenance Of Gravity-Fed System In Rural Areas. Module 6: Hidraulic Ram Pump System.

[9]. Lafaliana, M. N, Dkk., 2011, Perancangan Pompa Hidram Di Desa Banyusoca, Playen, Gunungkidul, Program Studi Fisika Teknik, Jurusan Teknik Fisika, Fakultas Teknik, Universitas Gadjah Mada Yogyakarta.

[10]. Mukhammad, S., Siregar, I. H., 2015, Pengaruh Ketinggian Terjunan Dan Volume Tabung Udara Terhadap Pompa Hidram, S1 Pendidikan Teknik Mesin, Fakultas Teknik, Universitas Negeri Surabaya.

[11]. Suarda, M., Wirawan, IKG, 2008, Kajian Eksperimental Pengaruh Tabung Udara Pada Head Tekanan Pompa Hidram, Jurnal Ilmiah Teknik Mesin CAKRAM, Vol. 2,
No.1, Jurusan Teknik Mesin, Universitas Udayana, Kampus Bukit Jimbaran Bali. 